Check for updates

The BMJ

fgodlee@bmj.com Follow Fiona on Twitter @fgodlee

Cite this as: BMJ2021;373:n1100 http://dx.doi.org/10.1136/bmj.n1100 Published: 29 April 2021

\title{
Covid-19: How can we keep the world's doctors safe?
}

\section{Fiona Godlee executive editor}

The world's doctors have been at the forefront of the pandemic response. Already overstretched by workforce shortages, they have carried exhaustion, uncertainty, and risk, redeploying to unfamiliar specialties, learning at speed, and adopting different ways of working and new technology, ${ }^{1}$ while all the time fearing for their patients, their families, and themselves. For many there has been the added burden of betrayal by governments, whose decisions have caused avoidable harm through waste, corruption, and incompetence and through policies driven by ideology rather than evidence. ${ }^{23}$

Nothing shows this more starkly than the events unfolding in Myanmar and India. Doctors who have joined peaceful protests against the military regime in Myanmar are being assaulted, shot at, and arbitrarily arrested. ${ }^{4}$ Reports of patients voluntarily leaving hospital in support of striking medical staff reflect the extent of the public's despair. ${ }^{5}$

In India, pictures of exhausted doctors and nurses tell a different but equally dreadful tale, with shortages of oxygen and other essential supplies, ${ }^{6}$ as the official but almost certainly underestimated death toll heads towards 200000.

Countries and colleagues around the world are at last responding. Medical organisations have condemned the targeting of doctors in Myanmar. ${ }^{7}$ And desperately needed supplies are arriving in India, although not yet the US's unused stockpile of the Oxford-AstraZeneca vaccine. ${ }^{8}$ Meanwhile senior UK doctors of Indian origin have proposed a plan to tackle the healthcare crisis, including a call for a ban on mass gatherings and postponement of the forthcoming elections. ${ }^{9}$

The role of mass gatherings in the spread of covid 19 remains a subject for debate, and with it the question of whether people should be encouraged or even required to wear masks outside. ${ }^{10}{ }^{11} \mathrm{As}$ for indoor transmission, official guidance has yet to reflect the growing evidence on airborne spread, ${ }^{12}$ but the UK government's advisers seem to be heading towards recommending what many think is long overdue: higher grade face masks for all staff who care for patients with suspected or confirmed covid-19. ${ }^{13}$ Mandatory vaccination for healthcare workers is not, however, being considered. ${ }^{14}$

As the pandemic continues, how can we properly look after doctors so they can look after their patients and communities? We need to focus on the big ticket items on which a better future for all of us depends: good governance, equitable healthcare, universal health coverage, and action on climate change. ${ }^{15} \mathrm{But}$ there are other, no less important acts that will help protect doctors, not least providing proper personal protective equipment (https://www.bmj.com/wellbeing) and enabling and encouraging mutual support. ${ }^{16}$
Salisbury H. Helen Salisbury: Let’s talk about sustainability. BMJ 2021;373:n1082doi: 10.1136/bmj.n1082.

2 Abbasi K. Covid-19: politicisation, "corruption," and suppression of science. BMJ 2020;371:m4425. doi: 10.1136/bmj.m4425 pmid: 33187972

3 Raffle AE, Gill M. Mass screening for asymptomatic SARS-CoV-2 infection. BMJ2021;373:n1058

4 Dyer O. Myanmar coup regime targets striking doctors with bullets, arrests, and erasures. BMJ2021;373:n1076.

doi: 10.1136/bmi.n1076 pmid: 33893072

5 Myanmar's doctors are risking their lives in the civil disobedience movement. BMJ Opinion. 21 Apr 2021.

https://blogs.bmj.com/bmi/2021/04/21/myanmars-doctors-are-risking-theirlives-in-the-civil-disobedience-movement.

6 Bhuyan A. Covid-19: India looks to import oxygen as cases surge, overwhelming hospitals. BM/2021;373:n1061.

doi: 10.1136/bmj.n1061 pmid: 33888471

7 Mahase E. Myanmar: Medical organisations unite to condemn attacks on healthcare workers. BMJ2021;373:n1097doi: 10.1136/bmj.n1097.

8 Wise J. Covid-19: Countries rally to support India through "storm that has shaken the nation". BMJ2021;373:n1086. doi: 10.1136/bmi.n1086 pmid: 33903127

9 Banerjee A, Patel K, Hanif W, et al. Open letter from trustees of South Asian Health Foundation: covid-19 call to action on global inequalities [electronic response to Wise J. Covid-19: Countries rally to support India through "storm that has shaken the nation"]. BMJ Apr 2021. https://www.bmj.com/content/373/bmj.n1086/rr.

10 Javid B, Bassler D, Bryant MB, Cevik M, Tufekci Z, Baral S. Should masks be worn outdoors?BM/2021:373:n1036.

11 Price A. Why I wear a mask indoors and out. BMJ2021;373:n1055.

12 Baraniuk C. Covid-19: What do we know about airborne transmission of SARS-CoV-2?BM/2021;373:n1030. doi: 10.1136/bmi.n1030 pmid: 33888460

13 Mahase E. Covid-19: Wider use of FFP3 masks may needed because of airborne transmission, say scientific advisors. BMJ2021;373:n1089. doi: 10.1136/bmj.n1089 pmid: 33903128

14 Wise J. Covid-19: Is the UK heading towards mandatory vaccination of healthcare workers?BM/2021;373:n1056. doi: 10.1136/bmi.n1056 pmid: 33883193

15 Laybourn-Langton L, Stott R. President Biden's leadership on climate mus be supported and applauded by health professionals. BMJ Opinion. $22 \mathrm{Apr}$ 2021. https://blogs.bmj.com/bmj/2021/04/22/president-bidens-leadershipon-climate-must-be-supported-and-applauded-by-health-professionals.

16 Gerada C. Clare Gerada: A problem shared. BMJ 2021;373:n1074doi: 10.1136/bmi.n1074.

This article is made freely available for use in accordance with BMJ's website terms and conditions for the duration of the covid-19 pandemic or until otherwise determined by BMJ. You may use, download and print the article for any lawful, non-commercial purpose (including text and data mining) provided that all copyright notices and trade marks are retained. 